\title{
PANDANGAN HUKUM ISLAM, HUKUM PERKAWINAN DAN KHI TERHADAP PRAKTEK NIKAH TAHLIL (Studi Kasus Di Desa Suka Jaya Kecamatan Muko-Muko Bathin VII Kabupaten Bungo)
}

\author{
Sopriyanto \\ Institut Agama Islam Yasni Bungo \\ Email: Sopriyantomunez1@gmail.com
}

\begin{abstract}
Abstrak
Penelitian ini di awali dengan kegelisahan penulis terhadap praktek Nikah Tahlil yang dilakukan oleh masyarakat desa Suka Jaya Kecamatan Muko-Muko Bathin VII. peneliti mengkaji tentang pandagan hukum Islam, Hukum Perkawinan dan KHI terhadap praktek tersebut. Hal yang menggelisahkan peneliti dalam penelitian ini adalah melihat fakta bahwa praktek nikah tahlil masih dilakukan setidaknya ada 3 orang laki-laki yang mau menjadi muhallil. Peneliti ingin mengetahui bagaimana praktek tersebut dalam pandanganhkum. peneliti menggunakan pendekatan kualitatif dengan analisis deskripstif. Instrumen yang digunakan dalam penelitian ini adalah data dokumentasi tertulis dan lembaran wawancara langsung. Hasil penelitian menujukkan bahwa praktek nikah tahlil dilakukan tanpa dicatatkan dan nikah tahlil ini dilakukan oleh orang yang bercerai tiga kali kemudian ingin rujuk. Dalam hukum Islam praktek nikah tahlil bertentangan dengan hukum islam, hukum perkawinan dan KHI.
\end{abstract}

Kata kunci: Hukum Islam, Hukum Perkawinan dan KHI, Nikah Tahlil.

\begin{abstract}
This research begins with the writer's anxiety about the practice of Tahlil marriage conducted by Suka Jaya village community, Muko-Muko Bathin VII sub-district. The researcher examined about Islamic law, Marriage Law and KHI views on the practice. What disturbs the researchers in this study is seeing the fact that the practice of marriage tahlil is still done at least there are 3 men who want to be Muhallil. Researchers want to know how the practice is in view of the law. researchers used a qualitative approach with descriptive analysis. The instruments used in this study were written documentation data and direct interview sheets. The results showed that the practice of tahlil marriages was carried out without being recorded and the tahlil marriages were carried out by divorced people three times then wanted to be reconciled. In Islamic law the practice of tahlil marriage is contrary to Islamic law, marriage law and KHI.
\end{abstract}

Keywords: Islamic Law, Marriage Law and KHI, Tahlil Marriage.

Nur El-Islam, Volume 6, Nomor 1, April 2019 


\section{A. Pendahuluan}

\section{Latar Belakang}

Syariat Islam orisinil dari segi pembentukan, dan sangat mandiri dari aspek sumber, semua kesesuaian kelanggengannya diambil dari dirinya sendiri dan tidak mengambil dasar atau meminjam hukum dari syariat lain. Syariat Islam juga tidak meniru undang-undang dari luar yang tidak ada di dalam dan menjadi bagian inti darinya dan tidak adahal yang aneh dalam hal ini karena syariat Islam berasal dari sisi Allah yang dibawa oleh Muhammad SAW. berupa wahyu dan syariat yang abadi. Berbeda dari syariat dan undang-undang yang lain dengan segala orisinilitasnya, syariat islam lebih utuh dari yang lain dalam segala hukum dan permasalahannya. ${ }^{1}$

Salah satu contoh hubungan antara sesama manusia yang ditetapkan Allah SWT adalah aturan pernikahan, karena manusia merupakan makhluk sosial yang hidup saling membutuhkan satu sama lain, maka Allah menciptakan manusia berapasang-pasangan agar kebutuhan biologis manusia terpenuhi serta melindungi manusia supaya terhindar dari yang namanya dosa atau murka dari Allah SWT.

Sebagaimana firman Allah dalam surat Al-Rum ayat 21 :

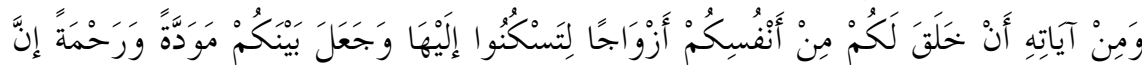

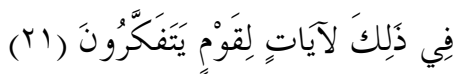

"Dan di antara tanda-tanda kekuasaan-Nya ialah Dia menciptakan untukmu isteri-isteri dari jenismu sendiri, supaya kamu cenderung dan merasa tenteram kepadanya, dan dijadikan-Nya diantaramu rasa kasih dan sayang. Sesungguhnya pada yang demikian itu benar-benar terdapat tanda-tanda bagi kaum yang berfikir.” (QS. Al-Rum/30:21)

Namun di desa Suka Jaya Kecamatan Muko-Muko Bathin VII Kabupaten Bungo, Jambi, nikah tahlil ini masih dilakukan dengan

\footnotetext{
${ }^{1}$ Rasyad Hasan Khalil, Tarikh Tasyri', (Jakarta: Amzah, 2009) h. 19
} 
tujuan untuk menghalalkan perempuan yang telah di talak tiga oleh bekas suaminya, agar bekas suaminya ini dapat kembali menikahi perempuan tersebut. Akad nikah tahlil dilakukan hanya dihadiri oleh beberapa orang saja, tanpa adanya walimah atau resepsi pernikahan.

Mengenai pernikahan tahlil, ada beberapa bentuk akad terhadap kesepakatan penghalalan dan persyaratan terhadap penghalal, diantaranya:

a. Jika suami kedua berakad nikah dan mensyaratkan di tengahtengah akad agar menceraikannya setelah bercampur atau apabila telah bercampur, mereka terpisah atau tidak ada lagi pernikahan antara mereka berdua.

b. Jika kedua belah pihak sebelum akad sepakat talak sesudah bercampur tetapi mereka tidak mempersyaratkannya di tengahtengah akad. Pernikahan seperti ini hukumnya makruh karena keluar dari perbedaan orang yang mengharamkan.

c. Jika ia menikahinya tanpa syarat, tetapi niatnya menceraikan setelah bercampur, ia berakad di hadapan orang banyak bahwa akad yang dilakukan adalah akad selamanya.akad dalam kondisi tersebut sah tetapi makruh, jika ia menjatuhkan talak setelah bercampur maka halal bagi suami pertama setelah habis masa iddahnya. $^{2}$

\section{Identifikasi Masalah}

Adapun yang menjadi masalah dalam penelitian ini adalah

a. Masih dilakukan praktek nikah tahlil di desa Suka Jaya Kecamatan Muko-Muko Bathin VII

b. Bertentangan dengan aturan syariat Islam, Hukum perkawinan dan Kompilasi Hukum Islam

3. Teori dan Kajian Terdahulu

a. Da'in Fazani dari Institut Agama Islam Negeri Wali Songo Semarang pada tahun 2010, dengan judul Analisis Pendapat

\footnotetext{
${ }^{2}$ Abdul Aziz Muhammad Azzam dkk, Fiqih Munakahat (Jakarta: Amzah, 2009), h.
} 
Imam Syafi'I Tentang sahnya Nikah Muhallil. Dalam skripsi ini, penulisnya membahas tentang metodologi yang digunakan imam Syafi'I tentang kebolehan nikah Tahlil, kemudian hasil penelitiannya bahwa menurut Imam Syafi'I Nikah Tahlil hukumnya sah dan diperbolehkan, dengan menggunakan metode ijtihad Qiyas. Perbedaannya adalah penulis terdahulu membahas pendapat imam Syafi'i Saja, sedangkan dalam jurnal penulis membahas dalam persfektif hukum Islam, Hukum Perkawinan dan Kompilasi Hukum Islam. Persamaannya adalah sama-sama menggunakan metode kualitatif.

b. Ahmad Zarkasyi dari Uniersitas Islam Negeri Syarif Kasim dengan judul NIkah Muhallil Menurut Imam Hanafi pada tahun 2011, hasil penelitiannya adalah pendapat imam Hanafi mengesahkan nikah tahlil dan ulama mujtahid lainnya. Sedangkan dalam penelitian penulis membahas tentang masyarakat dan tinjauan hukum islam, hukum perkawinan dan kompilasi hukum islam. Persamaannya adalah samasama menggunakan metode kualitatif

\section{Tujuan Penelitian}

Berdasarkan identifikasi masalah di atas, maka tujuan dari penelitian ini adalah untuk:

a. Menganalisis bagaimana praktek Nikah Tahlil yang dilakukan di desa Suka Jaya kecamatan Muko-Muko Bathin VII

b. Menganalisis bagaimana pandangan Hukum Islam, Hukum Positif dan Kompilasi Hukum Islam terhadap praktek Nikah Tahlil.

\section{Metodologi Penelitian}

Sistem pendekatan dalam kegiatan penelitian seperti ini juga sering disebut penelitian deskriptif, yang merupakan penelitian yang dimaksudkan untuk mengumpulkan data maupun informasi mengenai suatu gejala yang ada, yaitu keadaan gejala menurut apa adanya pada saat penelitian dilakukan. Apabila 
peneliti melakukan pencatatan pertama pada bulan juni, maka pencatatan-pencatatan berikutnya juga harus dilakukan pada bulan yang sama sehingga kondisinya sama". ${ }^{3}$

Menurut Creswel dalam Mukhtar menyebutkan bahwa karakter utama dalam penelitian kualitatif adalah: pertama: penelusuran masalah dan pengembangan sacara detail terpusat pada suatu fenomena tertentu. Kedua, teori dan peraturan yang digunakan menjadi sandaran dalam merumuskan masalah. Ketiga , dalam merumuskan masalah dan pertanyaan penelitian serta tercapainya tujuan penelitian secara umum, ditentukan oleh pengalaman langsung peneliti berpartisipasi dalam sosial pada studi pendahuluan hingga proses penelitian yang dilaksanakan. Keempat, pengumpulan data bertolak pilihan kata yang sederhana. Kelima, analisis data yang dideskripsikan dan tematema yang ditampilkan dalam analisis diinterpretasikan menjadi makna. 9 Pendekatan kualitatif merupakan metode-metode untuk mengeksplorasi dan memahami makna yang oleh sejumlah individu atau sekelompok orang dianggap berasal dari masalah sosial.

\section{B. Pembahasan}

1. Landasan Teori

a. Pengertian Perkawinan

Dalam pasal 1 ayat 2 Undang-Undang No. 1 tahun 1974 tercantum pengertian perkawinan yaitu "Ikatan lahir batin antara seorang pria dan seorang wanita sebagai suami istri dengan tujuan membentuk keluarga, rumah tangga yang bahagia dan kekal berdasarkan Ketuhanan Yang Maha Esa”. ${ }^{4}$

Nikah menurut Kamus Besar Bahasa Indonesia adalah ikatan (akad) perkawinan yang sesuai dengan ketentuan hukum dan ajaran

${ }^{3}$ Suharsimi Arikunto, Prosedur Penelitian Suatu Pendekatan Praktik, (Jakarta : Rineka Cipta, 2010), hlm. 15

${ }^{4}$ Undang-Undang Nomor 1 Tahun 1974 
agama. Hidup sebagai suami istri tanpa ikatan merupakan pelanggaran terhadap agama dan hukum. ${ }^{5}$

Pernikahan ditinjau dari segi bahasa adalah bersatu dan bergabung dan diantara mereka mengatakan sebuah pohon bergabung apabila bergabung sebagiannya dengan yang lain. Dan menurut istilah adalah akad yang menyebabkan kebolehan untuk bersenang-senang dengan lafaz nikah atau kawin dan ini merupakan hakikat sebuah akad dan majaz untuk wat-un atau bersetubuh. ${ }^{6}$

Di dalam kitab bajuri dijelaskan bahwa pernikahan adalah sesuatu akad yang mengandung atas rukun-rukun dan syarat-syarat yang mengakibatkan kebolehan untuk bersetubuh. ${ }^{7}$ Di dalam Kamus Besar Bahasa Indonesia,dijelaskan bahwa pengertian tahlil adalah pernikahan yang dilakkan oleh orang ketiga untuk meghalalkan bekas suami yang telah menjatuhkan talak tiga untuk kembali kepada bekas istrinya. ${ }^{8}$

Sebagaimana telah dijelaskan dalam Al-Quran bahwa orang yang telah ditalak tiga oleh suaminya kemudian mereka ingin rujuk kembali maka haruslah menikah dengan laki-laki lain terlebih dahulu, sebagaimana firman Allah SWT dalam surat Al-Baqarah ayat 230:

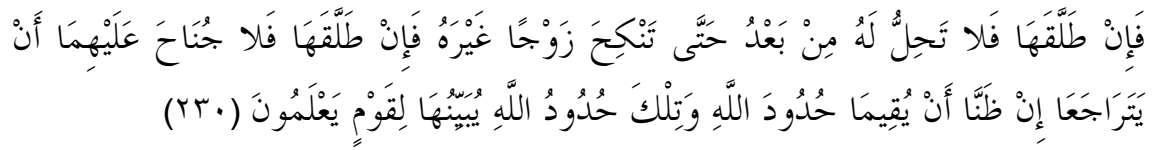

"Kemudian jika si suami mentalaknya (sesudah Talak yang kedua), Maka perempuan itu tidak lagi halal baginya hingga Dia kawin dengan suami yang lain. kemudian jika suami yang lain itu menceraikannya, Maka tidak ada dosa bagi keduanya (bekas suami pertama dan isteri) untuk kawin kembali jika keduanya berpendapat akan dapat menjalankan hukumhukum Allah. Itulah hukum-hukum Allah, diterangkan-Nya

\footnotetext{
${ }^{5}$ Kamus Besar Bahasa Indonesia

${ }^{6}$ Zainuddin Abdul Aziz, Fathul Mu’in bi Syarhi Qurratul 'ain, h. 97-98

${ }^{7}$ Ibnu Qasim AL-Ghazi, Al-Bajuri (An-Nasir: Maktabah Wahdan indonesia), h. 90

${ }^{8}$ Kamus Besar Bahasa Indonesia
} 
kepada kaum yang (mau) mengetahui.” (QS alBaqarah/2:230).

Menurut Amir Syarifuddin nikah tahlil secara etimologi berarti menghalalkan hukumnya adalah haram. Kalau dikaitkan dengan perkawinan akan bearti perbuatan yang menyebabkan seseorang yang semula haram melangsungkan perkawinan menjadi boleh atau halal. Orang yang dapat menyebabkan halalnya orang lain melakukan perkawinan itu disebut muhallil, sedangkan orang yang telah halal melakukan perkawinan disebabkan oleh perkawinan yang dilakukan muhallil disebut muhallal lahu.

Dengan demikian Nikah Tahlil adalah perkawinan yang dilakukan untuk menghalalkan orang yang telah melakukan talak tiga untuk segera kembali kepada istrinya dengan nikah yang baru. ${ }^{9}$

Allah menurunkan syari'at pernikahan untuk dijadikan dasar yang kuat bagi kehidupan manusia karena adanya beberapa nilai yang tinggi dan beberapa tujuan yang baik bagi manusia, makhluk yang dimuliakan Allah.Untuk mencapai kehidupan yang bahagia dan menjauhi dari ketimpangan dan penyimpangan, Allah telah membekali dengan hukum-hukum Islam agar dilaksanakan manusia dengan baik. ${ }^{10}$

Dalam penafsirannya ayat ini mempunyai makna bahwa dengan melalui perkawinan dan kelahiran, maka lestarilah mata rantai kehidupan bagi jenis manusia, hinga sampai waktu yang ditentukan, maksudnya adalah waktu yang telah ditakdirkan oleh Allah SWT. Bagi masa berlakunya kehidupan ini. ${ }^{11}$

Rumah tangga adalah suatu kumpulan dari masyarakat terkecil, yang terdiri dari pasangan suami isteri, anak-anak, mertua dan sebagainya. Terwujudnya suatu rumah tangga yang sah setelah

\section{h. 103-104}

${ }^{9}$ Amir Syarifuddin, hukum perkawinan Islam di Indonesia (jakarta: kencana, 2007)

${ }^{10}$ Abdul Aziz Muhammad Azzam dan Abdul Wahhab Sayyed Hawwas, Fiqh Munakahat, (Jakarta: Amzah, 2009), h. 39.

${ }^{11}$ Kementerian Agama RI, Ahmad Mustafa AL-Maraghi, Terjemah Tafsir AlMaraghi Juz 21. (Semarang: PT. Karya Toha Putra, tt), h. 53 
didahului oleh Aqad Nikah atau Perkawinan sesuai dengan ajaran Agama dan Undang-undang No. 1 tahun 1974 tentang Perkawinan.

Perkawinan harus diawali dengan niat yang ikhlas karena Perkawinan itu adalah suruhan Allah dan RasulNya terhadap Hambanya yang mampu.Sebelumnya pihak-pihak yang bersangkutran (calon suami isteri) hendaklah berusaha mempelajari dasar-dasar dan tujuan berumah tangga serta seluk beluk pernikahan yang bersangkutan dengan itu.

Hal itu dimaksudkan supaya landasan atau pondamen rumah tangga yang akan didirikan itu lebih baik dan lebih kuat, tidak mudah mengalami kegoncangan dan krisis dalam melayarkan bahtera rumah tangga berikutnya. Selanjutnya perhatikanlah uraian-uraian ringkas tentang tujuan dan hakekat Perkawinan, baik menurut ajaran Agama maupun menurut Undang-undang No. 1 tahun 1974, serta pengaruhnya lingkungan dan masyarakat, Bangsa dan Agama. ${ }^{12}$

\section{b. Manfaat dan Tujuan Perkawinan}

Manfaat Perkawinan itu telah dirasakan oleh setiap orang yang berumah tangga antara lain, terdapatnya kepuasan dan ketenangan jiwa (hati), rasa kasih sayang terhadap isteri dan anak-anak yang dilandasi dengan rasa tanggung jawab, baik di bidang kesejahteraan lahiriyah dan batiniyahnya, seperti membentuk keperibadian anak atau keluarga dengan ajaran Agama dan ilmu pengetahuan lainnya, dengan tujuan agar terwujud rumah tangga yang sejahtera, bahagia lahir dan batin, memperoleh keturunan yang sah, suci dimasa yang akan datang. ${ }^{13}$

Tujuan pernikahan dalam Islam tidak hanya sekadar pada batas memenuhi kebutuhan biologis atau pelampiasan nafsu seksual, tetapi memiliki tujuan-tujuan penting yang berkaitan dengan sosial, psikologi, dan agama.

${ }^{12}$ Sidi Nazar Bakri, Kunci Keutuhan Rumah Tangga, (Jakarta: CV. Pedoman Ilmu Jaya, 1993), h. 26.

${ }^{13}$ Ibid., h. 27. 
Allah menurunkan syari'at pernikahan untuk dijadikan dasar yang kuat bagi kehidupan manusia karena adanya beberapa nilai yang tinggi dan beberapa tujuan yang baik bagi manusia, makhluk yang dimuliakan Allah.Untuk mencapai kehidupan yang bahagia dan menjauhi dari ketimpangan dan penyimpangan, Allah telah membekali dengan hukum-hukum Islam agar dilaksanakan manusia dengan baik. ${ }^{14}$

Sebagaimana firman Allah SWT

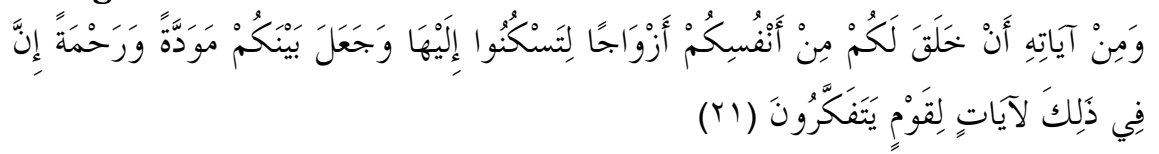

Dan di antara tanda-tanda kekuasaan-Nya ialah Dia menciptakan untukmu isteri-isteri dari jenismu sendiri, supaya kamu cenderung dan merasa tenteram kepadanya, dan dijadikan-Nya diantaramu rasa kasih dan sayang. Sesungguhnya pada yang demikian itu benar-benar terdapat tanda-tanda bagi kaum yang berfikir. (QS. Al-Rum/30:21).

Dalam penafsirannya ayat ini mempunyai makna bahwa dengan melalui perkawinan dan kelahiran, maka lestarilah mata rantai kehidupan bagi jenis manusia, hinga sampai waktu yang ditentukan, maksudnya adalah waktu yang telah ditakdirkan oleh Allah SWT. Bagi masa berlakunya kehidupan ini. ${ }^{15}$

Rumah tangga adalah suatu kumpulan dari masyarakat terkecil, yang terdiri dari pasangan suami isteri, anak-anak, mertua dan sebagainya. Terwujudnya suatu rumah tangga yang sah setelah didahului oleh Aqad Nikah atau Perkawinan sesuai dengan ajaran Agama dan Undang-undang No. 1 tahun 1974 tentang Perkawinan.

Perkawinan harus diawali dengan niat yang ikhlas karena Perkawinan itu adalah suruhan Allah dan RasulNya terhadap Hambanya yang mampu.Sebelumnya pihak-pihak yang bersangkutran

${ }^{14}$ Hawwas, Fiqh Munakahat, h. 39.

${ }^{15}$ AL-Maraghi, Terjemah Tafsir Al-Maraghi Juz 21, h. 53 
(calon suami isteri) hendaklah berusaha mempelajari dasar-dasar dan tujuan berumah tangga serta seluk beluk pernikahan yang bersangkutan dengan itu.

Hal itu dimaksudkan supaya landasan atau pondamen rumah tangga yang akan didirikan itu lebih baik dan lebih kuat, tidak mudah mengalami kegoncangan dan krisis dalam melayarkan bahtera rumah tangga berikutnya. Selanjutnya perhatikanlah uraian-uraian ringkas tentang tujuan dan hakekat Perkawinan, baik menurut ajaran Agama maupun menurut Undang-undang No. 1 tahun 1974, serta pengaruhnya lingkungan dan masyarakat, Bangsa dan Agama. ${ }^{16}$

\section{Pembahasan Hasil Penelitian}

\section{a. Hasil Penelitian}

Masyarakat di kecamatan Muko-muko Bathin VII khususnya di Desa Suka Jaya yang melakukan praktek nikah tahlil dengan menyebutkan beberapa alasan yang kemudian didukung oleh beberapa tokoh masyarakat dengan berbagai macam pertimbangan yang selanjutnya disebut tokoh tokoh agama/ Ulama.

Praktek nikah tahlil di desa Suka Jaya ini dilakukan dengan beberapa faktor diantaranya adalah:

1) Jika pasangan suami istri yang bercerai sampai tiga kali atau istrinya sudah ditalak sampai tiga kali, dan mereka ingin rujuk kembali, maka disyaratkan agar istrinya harus menikah terlebih dahulu dengan laki-laki lain. Sebagaimana firman Allah SWT.

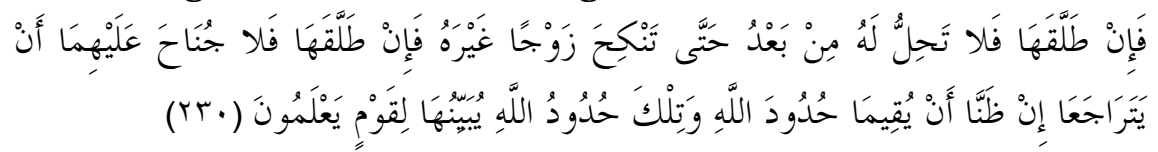

"kemudian jika si suami mentalaknya (sesudah Talak yang kedua), Maka perempuan itu tidak lagi halal baginya hingga Dia kawin dengan suami yang lain. kemudian jika suami yang lain itu menceraikannya, Maka tidak ada dosa bagi keduanya (bekas suami pertama dan isteri) untuk kawin kembali jika keduanya

${ }^{16}$ Bakri, Kunci Keutuhan Rumah Tangga, h. 26. 
berpendapat akan dapat menjalankan hukum-hukum Allah. Itulah hukum-hukum Allah, diterangkan-Nya kepada kaum yang (mau) mengetahui." (QS. Al-Baqarah/2:230).

2) Menurut adat yang berlaku di desa Suka Jaya, pernikahan tahlil ini dibolehkan dengan landasan hukum adatnya adalah wajib segera itu ada empat hal yaitu:

a) Menuntut akan kawin

b) Cerai akan rujuk

c) Kafir masuk Islam

d) Orang meninggal dunia

Empat hal ini menurut adat yang berlaku di desa Suka Jaya harus segera dilaksanakan, karena hal ini merupakan sesuatu yang sangat penting dan jika tidak dilaksanakan dengan cepat maka berdosa.

Dalam hal ini yang menjadi topik pembicaraannya adalah orang yang telah talak tiga dan mereka ingin rujuk kembali. Syarat untuk bias rujuk kembali dengan mantan istrinya adalah harus dilakukan pernikahan terlebih dahulu terhadap wanita tersebut dengan laki-laki selain suaminya.

1. Praktek nikah tahlil ini sudah dilakukan sejak zaman nenek moyang dahulu, sampai sekarang tetap di bolehkan karena jika perempuan yang telah di talak tiga oleh suaminya itu dan belum menikah dengan laki-laki lain atau belum ditahlil kemudian mereka ingin rujuk dan lari kedaerah lain yang masyarakat daerah itu tidak mengetahui bahwa mereka telah talak tiga, maka hukumnya adalah haram atau sama dengan zina.

2. Kemudian jika talak tiga itu tidak di tahlil secepatnya maka baik suami ataupun istri yang talak tiga itu akan mendapatkan kutukan dari yang maha kuasa, bahkan desapun juga akan mendapatkan kutukan, ini menurut hukum adat yang berlaku di desa ini sesuai larangan adat yang berbunyi:

"Jangankan semakan seminum setepianpun dilarang”

artinya orang yang talak tiga itu tidak boleh hidup bersama dalam sebuah daerah atau terjadi perbedaan status sosial dalam organisasi masyarakat. 
3. Akibat dari orang yang talak tiga baik bagi perempuan maupun bagi laki-laki, masyarakat adat desa suka jaya menyebutkan orang yang mabuk talak tiga seperti orang yang tidak waras lagi pikirannya ketika antara laki-laki dan perempuan tersebut ingin rujuk kembali. Mereka menyebutnya dengan istilah talak manjat dinding.

4. Mengenai bilangan talak yang dijatuhkan atau diucapkan kepada seorang perempuan para ulama dan tokoh adat di kecamatan muko-muko bathin VII menyebutkan bahwa walaupun di jatuhkan atau dikatakan dengan talak tiga, maka tetap jatuh talak satu, dengan alasan untuk mempersulit terjadinya perceraian di dalam sebuah rumah tangga.

Bagi muhallil faktor yang menyebabkan dia mau menjadi seorang muhallil secara umum beraneka ragam, berikut hasil wawancara penulis dengan para muhallil:

Castelo (nama samaran) bahwa dia telah menjadi muhallil sejak tahun 2003, alasan dia mau menjadi seorang muhallil adalah bahwa setiap laki-laki itu pasti membutuhkan perempuan dalam hidupnya dan laki-laki mana juga yang mampu menahan syahwatnya. Dan setelah dia melakukan pernikahan malah mendapatkan sejumlah uang, bahkan dia mengaku bahwa uang yang dia dapat ketika menikah tidak ada batasan jumlahnya.

Roger (nama samaran) bahwa alasan dia mau menjadi seorang muhallil relatif sama dengan responden sebelumnya, akan tetapi dia melakukan nikah tahlil ini selain mendapatkan sejumlah uang dia juga merasakan manisnya madu pernikahan.

Jhony (nama samaran) bahwa dia melakukan nikah tahlil ini dikarenakan hanya ingin membantu orang yang sudah talak tiga, karena kasian melihat anak-anaknya, karena orang tuanya telah berpisah, dan alasan lain adalah agar orang yang telah talak sampai tiga kali itu dapat kembali melanjutkan rumah tangganya, serta agar mereka terhindar dari dosa besar jika orang yang talak tiga ini rujuk ditempat lain tanpa ada pentahlilan terhadap istrinya terlebih dahulu. alasan ini juga seperti apa yang diungkap oleh rico (nama samaran). 


\section{b. Pembahasan}

Setelah melakukan wawancara secara mendalam terhadap tokoh masyarakat, ketua lembaga adat, pelaku nikah tahlil atau muhalil, dan para ulama yang berada didesa ini maka penulis dapat mengambil kesimpulan sebagai berikut:

Bahwa praktek nikah tahlil yang dilakukan di dusun Suka Jaya ini hukumnya adalah boleh, karena melakukan sesuatu untuk niat kebaikan terhadap orang lain.

Pernikahan tahlil baru akan dilakukan jika ada pasangan suami istri yang sudah bercerai sampai tiga kali, kemudian antara kedua belah pihak ingin rujuk kembali untuk melanjutkan rumah tangganya, maka harus dilakukan pernikahan tahlil sekalipun dengan cino buto ${ }^{17}$, hal ini dapat dilihat indikasinya bahwa orang yang mabuk talak tiga itu atau ingin kembali rujuk dengan jandanya, seperti orang yang kurang waras. Namun sebaliknya jika tidak ada kesepakatan kedua belah pihak maka tidak perlu dilakukan nikah tahlil.

Pernah ada suatu kejadian antara suami istri yang pernah bercerai sampai tiga kali, si suami setiap malam menemui jandanya dan ingin rujuk dengan mantan istrinya, dan kejadian inilah yang meresahkan warga, karena sudah melanggar tatanan adat dan etika, yaitu orang yang sudah bercerai sampai tiga kali tidak boleh hidup satu atap. Seperti seluko adat mengatakan "jangankan semakan seminum setepianpun tidak boleh" dalam arti kata bahwa orang yang bercerai sampai tiga kali tidak sama sekali untuk bertemu atau berkomunikasi, dikarenakan mudharat yang sangat besar.

Kemudian praktek nikah tahlil ini juga tidak fasid atau batal pernikahannya, walaupun pernikahan ini diniatkan untuk menghalalkan perempuan yang telah ditalak tiga oleh suaminya untuk kembali rujuk dengan suaminya tersebut, karena yang membatalkan suatu pernikahan bukanlah hal-hal yang diniatkan, tetapi sesuatu yang disyaratkan tidak penuhi maka batal suatu akad pernikahan.

\footnotetext{
${ }^{17}$ Istilah masyarakat setempat yang berarti orang yang tidak memiliki akal yang cukup sempurna
} 
Hal ini sesuai dengan pendapat imam As-Syafi'I sebagimana yang dikutip oleh Amir Syarifuddin Dalam bukunya yang berjudul Hukum Perkwinan Islam di Indonesia, bahwa jika didalam akad tidak tidak syarat untuk menceraikan perempuan tersebut setelah dukhul atau selainnya tetapi hanya diniatkan saja, maka hukum pernikahan tahlil tersebut adalah sah karena dalam akad perkawinan itu tidak terdapat adanya persyaratan. ${ }^{18}$

Akan tetapi sebuah akad perkawinan hanya batal dengan apa yang disyaratkan bukan dengan apa yang diniatkan. ${ }^{19}$ dengan demikian pernikahan tahlil yang dilakukan didesa suka jaya ini hukumnya sah karena dalam prakteknya akad yang dilangsung tidak ada syarat apapun.

Pernikahan tahlil ini tidak jauh berbeda dengan pernikahan biasa baik dari segi rukunnya maupun syaratnya, hanya saja yang ada perbedaan adalah pada syarat calon mempelai perempuan yaitu harus sudah di jatuhi talak tiga oleh suaminya.

Jika dilihat dari aspek peraturan perundang-undangan yang mengatur tentang perkawinan di indonesia, menjelaskan tentang tujuan utama dari suatu pernikahan adalah untuk membentuk suatu kelarga atau rumah tangga yang sakinah mawaddah warahmah, sebagaimana yang tertera dalam pasal Pasal 3 "perkawinan bertujuan untuk mewujudkan kehidupan rumah tangga yang sakinah, mawaddah, dan rahmah". ${ }^{20}$

hal ini memang bertentangan karena nikah tahlil tidak mempunyai tujuan untuk membentuk suatu keluarga sebagaimana yang ada di dalam aturan perundang-undangan. Akan tetapi pernikahan tahlil yang dilakukan didesa suka jaya, bertujuan untuk menghalalkan kembali wanita yang telah ditalak tiga oleh suaminya untuk kembali rujuk dengan suaminya tersebut. Artinya bertujuan untuk menmbantu suami istri tersebut melanjutkan rumah tangganya.

${ }^{18}$ Amir Syarifuddin, Hukum Perkawinan Islam di Indonesia (jakarta: kencana, 2007) h. 106

${ }^{19}$ Ibid., h. 107.

${ }^{20}$ Kompilasi Hukum Islam Bab II Dasar-Dasar Perkawinan 
Walaupun tidak untuk membentuk suatu keluarga, namun nikah tahlil juga sebagai antisipasi dari perbuatan zina jika suami istri itu pergi ke suatu tempat dan mereka menikah kembali tanpa ada pentahlilan terhadap perempuan itu terlebih dahulu. Perbuatan yang seperti ini merupakan suatu perbuatan yang sangat menentang hukum Allah SWT. dan merupakan suatu dosa besar.

\section{Penutup}

Setelah Dibahas dari temuan di lapangan maka dapat ditarik kesimpulan bahwa pernikahan tahlil menurut hukum Islam hukumnya adalah haram jika ada suatu syarat di dalam akadnya, namun jika tidak ada syarat didalam akadnya dan bertujuan untuk membentu orang tersebut tanpa ada rekayasa sedikitpun dalam akadnya maka nikah ini adalah sah, karena yang membatalkan suatu akad itu adalah syarat yang diucapkan dalam sebuah akad dan syarat itu tidak dapat dipenuhi.

Memang pernikahan tahlil ini bertentangan dengan hukum positif yang menjelaskan tujuan dari sebuah perkawinan, namun disisi lain pernikahan ini juga bertujuan untuk membantu orang yang telah talak sampai tiga kali untuk kembali melanjutkan rumah tangganya juga sebagai antisipasi jika suami istri tersebut menikah ditempat lain tanpa adanya pentahlilan terlebih dahulu.

Jadi menurut hukum positif tetap dilarang karena bertentangan dengan prinsip perkawinan yaitu akad yang mitsaqan ghalidzan, dan tujuan darip perkawinan yang tercantum dalam pasal 2 ayat 1 dan 2

\section{DAFTAR PUSTAKA}

Abdul Aziz Muhammad Azzam dan Abdul Wahhab Sayyed Hawwas, Fiqh Munakahat, Jakarta: Amzah, 2009.

Amir Syarifuddin, hukum perkawinan Islam di Indonesia Jakarta: kencana, 2007.

Ibnu Qasim AL-Ghazi, Al-Bajuri, An-Nasir: Maktabah Wahdan Indonesia. $\mathrm{tt}$ 
Kamus Besar Bahasa Indonesia

Kementerian Agama RI, Ahmad Mustafa AL-Maraghi, Terjemah Tafsir Al-Maraghi Juz 21. Semarang: PT. Karya Toha Putra, tt.

Kompilasi Hukum Islam Bab II Dasar-Dasar Perkawinan.

Rasyad Hasan Khalil, Tarikh Tasyri', Jakarta: Amzah, 2009.

Sidi Nazar Bakri, Kunci Keutuhan Rumah Tangga, Jakarta: CV. Pedoman Ilmu Jaya.

Suharsimi Arikunto, Prosedur Penelitian Suatu Pendekatan Praktik, Jakarta: Rineka Cipta, 2010.

Undang-Undang Nomor 1 Tahun 1974

Zainuddin Abdul Aziz, Fathul Mu’in bi Syarhi Qurratul 'ain 